\title{
Complete genome sequence of Allochromatium vinosum DSM 180
}

\author{
Thomas Weissgerber ${ }^{1}$, Renate Zigann', David Bruce ${ }^{2}$, Yun-juan Chang², John C. Detter², \\ Cliff Han $^{2}$, Loren Hauser ${ }^{2}$, Cynthia D. Jeffries' ${ }^{2}$, Miriam Land ${ }^{2}$, A. Christine Munk ${ }^{2}$, Roxanne \\ Tapia $^{2}$, Christiane Dahl ${ }^{*}$ \\ ${ }^{1}$ Institut für Mikrobiologie \& Biotechnologie, Rheinische Friedrich-Wilhelms-Universität \\ Bonn, Bonn, Germany \\ ${ }^{2}$ DOE Joint Genome Institute, Walnut Creek, California, USA
}

*Corresponding author: ChDahl@uni-bonn.de

Keywords: purple sulfur bacteria, Chromatiaceae, versatile

Allochromatium vinosum formerly Chromatium vinosum is a mesophilic purple sulfur bacterium belonging to the family Chromatiaceae in the bacterial class Gammaproteobacteria. The genus Allochromatium contains currently five species. All members were isolated from freshwater, brackish water or marine habitats and are predominately obligate phototrophs. Here we describe the features of the organism, together with the complete genome sequence and annotation. This is the first completed genome sequence of a member of the Chromatiaceae within the purple sulfur bacteria thriving in globally occurring habitats. The 3,669,074 bp genome with its 3,302 protein-coding and 64 RNA genes was sequenced within the Joint Genome Institute Community Sequencing Program.

Dedicated to Prof. Dr. Hans G. Trüper, Bonn, on the occasion of his $75^{\text {th }}$ birthday on March $16^{\text {th }}, 2011$, for his fundamental work on phototrophic sulfur bacteria.

\section{Introduction}

Anoxygenic purple sulfur bacteria are Gammaproteobacteria whereas chemotrophic sulfuroxidizing bacteria are found in four classes (Alphaproteobacteria, Betaproteobacteria, Gammaproteobacteria and Epsilonproteobacteria) of the Proteobacteria. Strain DSM 180' (= ATCC $17899=$ $\mathrm{D}=$ NBRC 103801) is the type strain of the species Allochromatium vinosum, which belongs to the Chromatiaceae, one of currently five families in the order Chromatiales. Species belonging to the families Chromatiaceae and Ectothiorhodospiraceae are mainly anoxygenic photolithoautotrophic bacteria, which are able to oxidize various sulfur compounds. Anoxygenic purple sulfur bacteria like $A$. vinosum flourish wherever light reaches sulfidic water layers or sediments and often occur as dense accumulations in conspicuous blooms in freshwater as well as in marine aquatic ecosystems. Here, they are major players in the reoxidation of sulfide produced by sulfate-reducing bacteria in deeper anoxic layers. In contrast to anoxygenic purple sulfur bacteria of the family Ecto- thiorhodospiraceae and the only very distantly related green sulfur bacteria, members of the family Chromatiaceae like $A$. vinosum store sulfur globules inside of the cells when oxidizing sulfide or thiosulfate. They have this trait in common with a large number of environmentally important chemotrophic sulfur oxidizers like Beggiatoa or the sulfur-oxidizing bacterial symbionts of marine animals like Riftia pachyptila or Olavius algarvensis. Anoxygenic purple sulfur bacteria are also important primary producers of fixed carbon (up to $83 \%$ of primary production in lakes can be anoxygenic) [1]. The $\mathrm{CO}_{2}$ is fixed at the expense of the energy derived from the virtually unlimited and environmentally safe source of sunlight. Simultaneous with the large scale conversion of $\mathrm{CO}_{2}$ into organic compounds, purple sulfur bacteria oxidize reduced sulfur compounds and use these as photosynthetic electron donors [2]. In almost all freshwater and marine photic-anoxic environments, purple and also green sulfur bacteria represent the dominant anoxygenic phototrophs. 
Only very few and atypical ecosystems heavily polluted with organic waste have been described in which phototrophic Alphaproteobacteria outnumber purple sulfur bacteria. In addition to their environmental importance, purple sulfur bacteria like $A$. vinosum have a long tradition of biotechnological application not only in waste remediation and removal of toxic compounds, e.g. odorous sulfur compounds like sulfide or even explosives [3-5], but also in the production of industrially relevant organochemicals such as vitamins or biopolyesters [6-8] and the production of biohydrogen [9].

Strains of all Allochromatium species were isolated from freshwater, brackish water and marine habitats. A. vinosum is environmentally abundant and occurs not only in pelagic communities but also in littoral sediments like sandy beaches, salt marches or intertidal mud flats. Here we present a summary classification and a set of features for $A$. vinosum strain DSM $180^{\mathrm{T}}$, together with the description of the complete genomic sequencing and annotation.

\section{Classification and features}

There are five described species currently belonging to the genus Allochromatium [10, Table 1] namely $A$. vinosum, $A$. minutissimum, $A$. warmingii, A. phaeobacterium and A. renukae. Figure 1 shows the phylogenetic neighborhood of $A$. vinosum DSM $180^{\mathrm{T}}$ in a $16 \mathrm{~S}$ rRNA based maximum likelihood phylogenetic tree. Based on 16S rRNA gene sequences the closest related type strain is $A$. minutissimum DSM $1376^{\mathrm{T}}$ with $98.4 \%$ sequence identity, while the other type strains of the genus Allochromatium share $93.8-97 \%$ sequence identity.
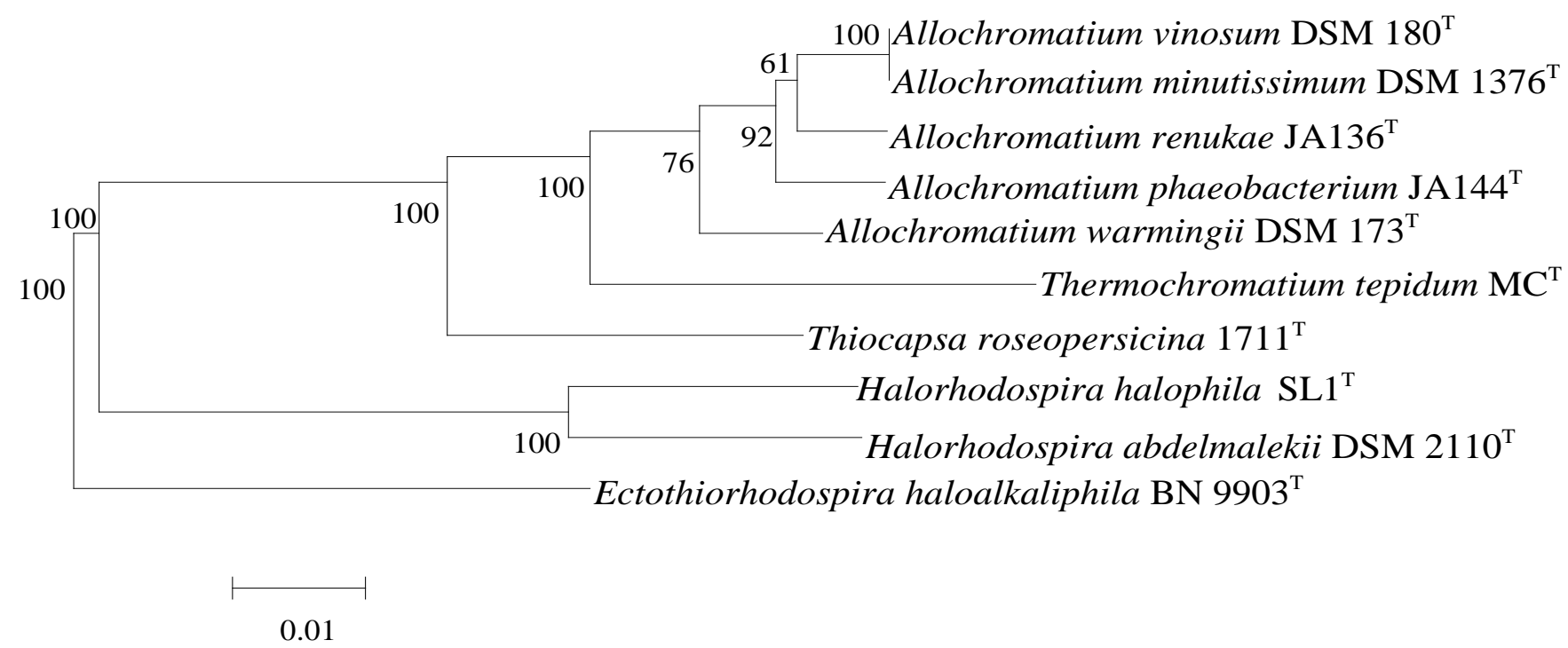

Figure 1. Phylogenetic tree highlighting the position of $A$. vinosum DSM $180^{\top}$ relative to several other type strains within the Chromatiaceae and Ectothiorhodospiraceae based on 16S rRNA sequence analysis. The tree was built with the RDP Tree Builder and numbers above branches are support values from 100 bootstrap replicates [25]. Bar, 1 nucleotide substitutions per 100 nucleotides.

Cells of $A$. vinosum are Gram stain negative, rod shaped and about $2.0 \mu \mathrm{m} \times 2.5-6 \mu \mathrm{m}$ in size [Figure 2]. There is a high intraspecies variation of the $\mathrm{G}+\mathrm{C}$ content within the genus Allochromatium. For example the $\mathrm{G}+\mathrm{C}$ content of $A$. vinosum $(64.3 \%)$ and $A$. warmingii (55.1-60.2\%) differs up to $10 \mathrm{~mol} \% \mathrm{G}+\mathrm{C}$ content of the DNA. Cells of all species are motile and contain internal membrane structures of a vesicular type. The main carotinoid synthesized by $A$. vinosum and A. minutissimum belongs to the group of spirilloxanthins, whereas
A. phaeobacterium and A. warmingii produce rhodopinals and $A$. renukae lycopenes, respectively. Optimal growth of $A$. vinosum is achieved within a temperature range between $25-35{ }^{\circ} \mathrm{C}$ and a $\mathrm{pH}$ range between 7.0-7.3, respectively [21].

Most purple sulfur bacteria grow preferentially by photolithoautotrophic oxidation of reduced sulfur compounds. However, A. vinosum is an ecologically significant, typically dominant inhabitant of intertidal sediments, i.e. a fluctuating environment in which redox conditions change rapidly within 
hours. A. vinosum has adapted to this environment and developed high metabolic versatility. While $A$. vinosum and $A$. minutissimum are capable of growing both photolithotrophically and chemolithotrophically the remaining species are obligate phototrophs. Photolithoautotrophic growth of $A$. vinosum occurs with hydrogen, sulfide, polysulfide, thiosulfate, sulfur and sulfite as electron donors. Light energy is used to transfer the electrons of these different compounds to the level of the more highly reducing electron carriers $\mathrm{NAD}(\mathrm{P})^{+}$and ferredoxin for reductive carbon dioxide fixation.
Photoorganoheterotrophic growth occurs with formate, acetate, propionate, butyrate, pyruvate, fumarate, succinate, malate and glycolate as organic electron donors. At reduced oxygen partial pressure even chemoorganoheterotrophic and chemolithoautotrophic growth in the dark is possible with oxygen as the terminal electron acceptor [26]. Under such conditions $A$. vinosum and A. minutissimum assimilate sulfate. This versatility is not shared by other anoxygenic phototrophic organisms like the green sulfur bacteria (Chlorobiaceae).

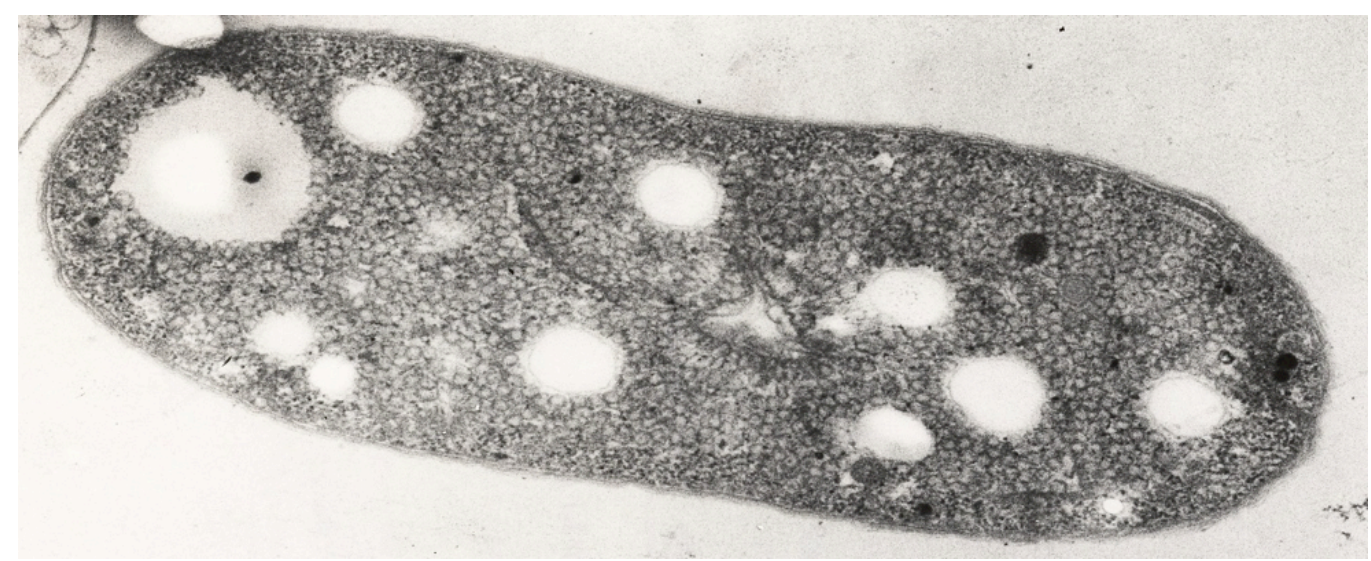

Figure 2. Transmission electron micrograph of a cell of $A$. vinosum strain 9011 (Photo kindly provided by Hans G. Trüper, Bonn). Magnification $\times 59,050$. As a result of the preparation for electron microscopy, the localization of sulfur globules is visible as "holes" in the electron micrograph.

\section{Genome sequencing and annotation Genome project history}

This organism was selected for sequencing on the basis of its environmental abundance and importance, its capability to produce hydrogen and its accessibility by manipulative genetics for biotechnology. The genome project is deposited in the Genomes OnLine Database [27] and the complete genome sequence is available in GenBank. Sequencing, finishing and annotation were performed by the DOE Joint Genome Institute (JGI). A summary of the project information is shown in Table 2.

\section{Growth conditions and DNA isolation}

A. vinosum DSM $180^{\mathrm{T}}$ was grown anaerobically in the light in RCV medium [28] at $30^{\circ} \mathrm{C}$. DNA was isolated from $50 \mathrm{mg}$ cell pellet by sarcosyl lysis according to the method of Bazaral and Helinski [29]. Briefly, the cell pellet was washed in TrisEDTA buffer at $\mathrm{pH} 8$, harvested and resuspended in $2 \mathrm{ml}$ ice-cold TES buffer at pH 8. Cells were harvested, mixed with $250 \mu$ sucrose solution $(20 \%$ $(\mathrm{w} / \mathrm{v})$ sucrose in TES) and incubated for $30 \mathrm{~min}$ on ice. Afterwards, $250 \mu \mathrm{l}$ of lysozyme RNAse solution (20 mg/ ml lysozyme, $1 \mathrm{mg} / \mathrm{ml}$ RNAse) were added followed by a further incubation for $30 \mathrm{~min}$ at $37{ }^{\circ} \mathrm{C}$ with gentle shaking. $100 \mu \mathrm{l}$ sarcosine solution $(10 \%(\mathrm{w} / \mathrm{v})$ laurylsarcosine, $250 \mathrm{mM}$ EDTA) were added and the sample was pressed through a sterile cannula $(1.2 \times 49 \mathrm{~mm})$. DNA purification was carried out by phenol/ chloroform extraction. Finally, purified DNA was transferred into Tris-EDTA buffer at $\mathrm{pH} 8$ by dialysis. The quality and quantity of extracted DNA was evaluated using the DNA Mass Standard Kit provided by the JGI. 


\section{Genome sequencing and assembly}

The genome of Allochromatium vinosum DSM 180 was sequenced at the Joint Genome Institute (JGI) using a combination of Illumina [30] and 454 technologies [31]. An Illumina GAii shotgun library with reads of $36 \mathrm{bp}$, a 454 Titanium draft library with average read length of 319.2 +/157.8 bp bases, and 2 paired end 454 libraries with average insert sizes of $15712+/-3928 \mathrm{bp}$ and $15,574+/-3,893 \mathrm{bp}$ were generated for this genome. All general aspects of library construction and sequencing performed at the JGI can be found at the JGI website [32]. Illumina sequencing data was assembled with VELVET [33], and the consensus sequences were shredded into $1.5 \mathrm{~kb}$ overlapped fake reads and assembled together with the 454 data. Draft assemblies were based on $238 \mathrm{Mb} 454$ draft data and approximately 48,000 per $\mathrm{Mb}$ paired end data. Newbler parameters are $\begin{array}{lllllllllll}\text { consed } & \text {-a } & 50 & \text {-l } & 350 & \text {-g } & \text {-mi } & 96 & \text {-ml } & 96 & \text {-o }\end{array}$ P_miml96_QD. The initial Newbler assembly contained 64 contigs in 41 scaffolds. The initial 454 assembly was converted into a phrap assembly by making fake reads from the consensus, collecting the read pairs in the 454 paired end library. The Phred/Phrap/Consed software package [34] was used for sequence assembly and quality assessment [35-37] in the following finishing process. After the shotgun stage, reads were assembled with parallel phrap (High Performance Software, LLC). Possible mis-assemblies were corrected with gapResolution (Cliff Han, unpublished), Dupfinisher [38], or sequencing cloned bridging PCR fragments with subcloning or transposon bombing (Epicentre Biotechnologies, Madison, WI). Gaps between contigs were closed by editing in Consed, by PCR and by Bubble PCR primer walks. A total of 174 additional PCR reactions were necessary to close gaps and to raise the quality of the finished sequence.

\section{Genome annotation}

Genes were identified using Prodigal [39] as part of the Oak Ridge National Laboratory genome annotation pipeline, followed by a round of manual curation using the JGI GenePRIMP pipeline [40]. The predicted CDSs were translated and used to search the National Center for Biotechnology Information (NCBI) nonredundant database, UniProt, TIGRFam, Pfam, PRIAM, KEGG, COG, and InterPro databases. These data sources were combined to assert a product description for each predicted protein. Non-coding genes and miscellaneous features were predicted using tRNAscan-SE [41], RNAMMer [42], Rfam [43], TMHMM [44], and SignalP [45].

\section{Genome properties}

The 3,669,074 bp genome consists of a 3,526,903 bp chromosome and two plasmids of $102,242 \mathrm{bp}$ and $39,929 \mathrm{bp}$, respectively. The genome exhibits an overall $\mathrm{G}+\mathrm{C}$ content of $64.19 \%$ (Table 3, Figure 3, and Figure 4). Of the 3,366 genes predicted, 3,302 are protein-coding genes and 64 RNAs; 82 pseudogenes were also identified. The majority of the protein-coding genes $(73.26 \%)$ were assigned a putative function while the remaining ones were annotated as hypothetical proteins. The distribution of genes into COGs functional categories is presented in Table 4.

\section{Insights from the genome sequence Extrachromosomal elements}

$A$. vinosum contains two extrachromosomal elements of 102,242 bp (pALVIN01) and 39,929 bp (pALVIN02), respectively, in accordance with previous analyses performed in our laboratory [46]. A third plasmid claimed by Gaju et al. 1995 is not present [47]. None of the genes identified on the plasmid encode for proteins of central metabolic pathways. It is noteworthy that plasmid pALVIN02 has a low GC content of only $53.5 \%$ as compared to the $64.26 \%$ and $61.9 \%$ of the main chromosome and pALVIN01, respectively.

\section{Phototrophy}

A. vinosum employs type II reaction centers to convert light energy into electrochemical energy. Three subunits of the photosynthetic reaction center, pufC, pufM and pufL are clustered and cotranscribed together with three sets of pufA and pufB genes encoding for light-harvesting complex (LH1) apoproteins (Alvin_2547-2555) [48]. Subunit four of the reaction center, $p u f H$, is located upstream, next to two genes encoding for photosynthetic complex assembly proteins and a hypothetical protein that probably constitutes an additional complex assembly protein (Alvin_26342637). Blast searches indicate that the genome contains six individual sets encoding for LH2 apoproteins, Alvin_0703-0706 and Alvin_0708-0709, which constitute one cluster together with lux genes, Alvin_2576-2579 and Alvin_2759-Alvin_2760. High copy numbers of different light harvesting subunits might allow adapting to alternating growth conditions such as light intensity or temperature [49]. 
Weissgerber et al.

The main carotenoids synthesized by $A$. vinosum belong to the group of spirilloxanthins. Genes necessary for spirilloxanthin biosynthesis starting from the C-5 compounds dimethylallyl-PP and isopentyl-PP are located next to each other from Alvin_2564 to Alvin_2570. A. vinosum utilizes only one type of bacteriochlorophyll (BChl), namely BChla. Genes necessary for conversion of the heme biosynthesis intermediate protoporphyrin IX into Bchla are partly distributed over the genome (Alvin_1182-1183, 2224, 2556, 2561-2563, 2632, 2638-2643 and 2645-2646).

Table 1. Classification and general features of A. vinosum DSM $180^{\top}$ according to the MIGS recommendations [11].

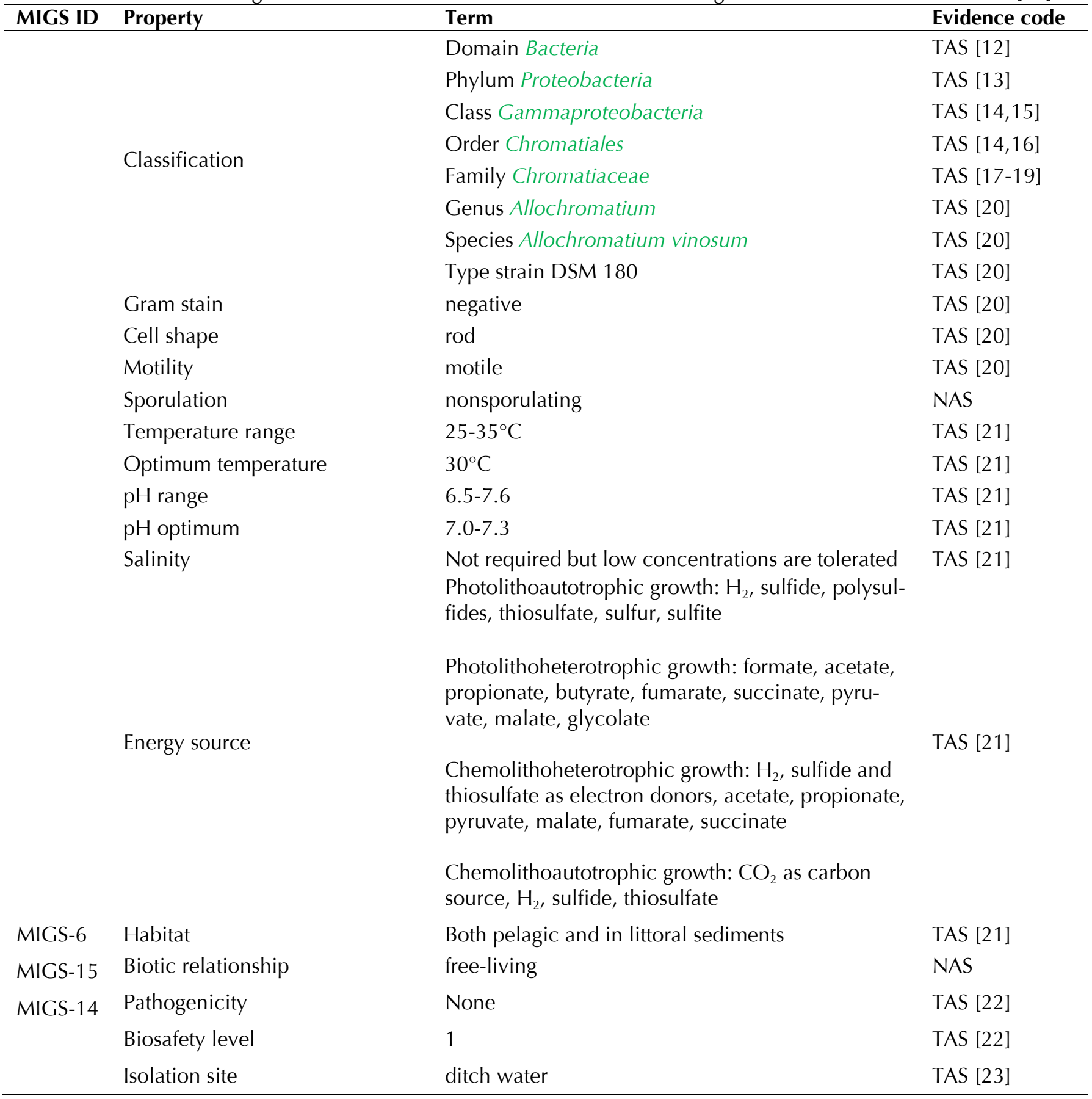

Evidence codes - IDA: Inferred from Direct Assay (first time in publication); TAS: Traceable Author Statement (i. e. a direct report exists in the literature); NAS: Non-traceable Author Statement (i. e. not directly observed for the living, isolated sample, but based on a generally accepted property for the species, or anecdotal evidence). These evidence codes are from the Gene Ontology project [24]. If the evidence code is IDA, then the property was directly observed for a living isolate by one of the authors or an expert mentioned in the acknowledgements. 
Table 2. Genome sequencing project information

\begin{tabular}{lll}
\hline MIGS ID & Property & Term \\
\hline MIGS-31 & Finishing quality & Finished \\
MIGS-28 & A Tibranium draft library $(319.2+/-157.8$ bp insert size), two paired \\
& & $\begin{array}{l}\text { end }(15,712+/-3,928 \text { bp, } 15,574+/-3,893 \text { bp insert sizes) and one } \\
\text { Illumina library (36 bp insert size) }\end{array}$ \\
MIGS-29 & Sequencing platforms & 454 Titanium, Illumina \\
MIGS-31.2 & Sequencing coverage & 136× 454 Titanium, 30× Illumina GAii \\
MIGS-30 & Assemblers & Newbler, phrap \\
MIGS-32 & Gene calling method & Prodigal, GenePRIMP \\
& & CP001896 (chromosome) \\
& INSDC ID & CP001897 (plasmid pALVIN01) \\
& & August 1, 2010 \\
& GenBank Date of Release & Gc01210 \\
& GOLD ID & 32547 \\
& NCBI project ID & 646564502 \\
& IMG Taxon ID & DSM 180 \\
& Source material identifier & Biotechnological, Environmental, Hydrogen production \\
\hline Project relevance &
\end{tabular}

Table 3. Genome Statistics

\begin{tabular}{lrr}
\hline Attribute & Value & \% of Total \\
\hline Genome size (bp) & $3,669,074$ & $100.00 \%$ \\
DNA coding region (bp) & $3,324,920$ & $90.62 \%$ \\
DNA G+C content (bp) & $2,355,037$ & $64.19 \%$ \\
Number of replicons & 3 & \\
Extrachromosomal elements & 2 & \\
Total genes & 3,366 & $100.00 \%$ \\
RNA genes & 64 & $1.90 \%$ \\
rRNA operons & 3 & \\
Protein-coding genes & 3,302 & $98.10 \%$ \\
Pseudo genes & 82 & $2.44 \%$ \\
Genes with function prediction & 2,466 & $73.26 \%$ \\
Genes in paralog clusters & 413 & $12.27 \%$ \\
Genes assigned to COGs & 2,505 & $74.42 \%$ \\
Genes assigned Pfam domains & 2,662 & $79.08 \%$ \\
Genes with signal peptides & 649 & $19.28 \%$ \\
Genes with transmembrane helices & 771 & $22.91 \%$ \\
CRISPR repeats & 3 & \\
\hline
\end{tabular}




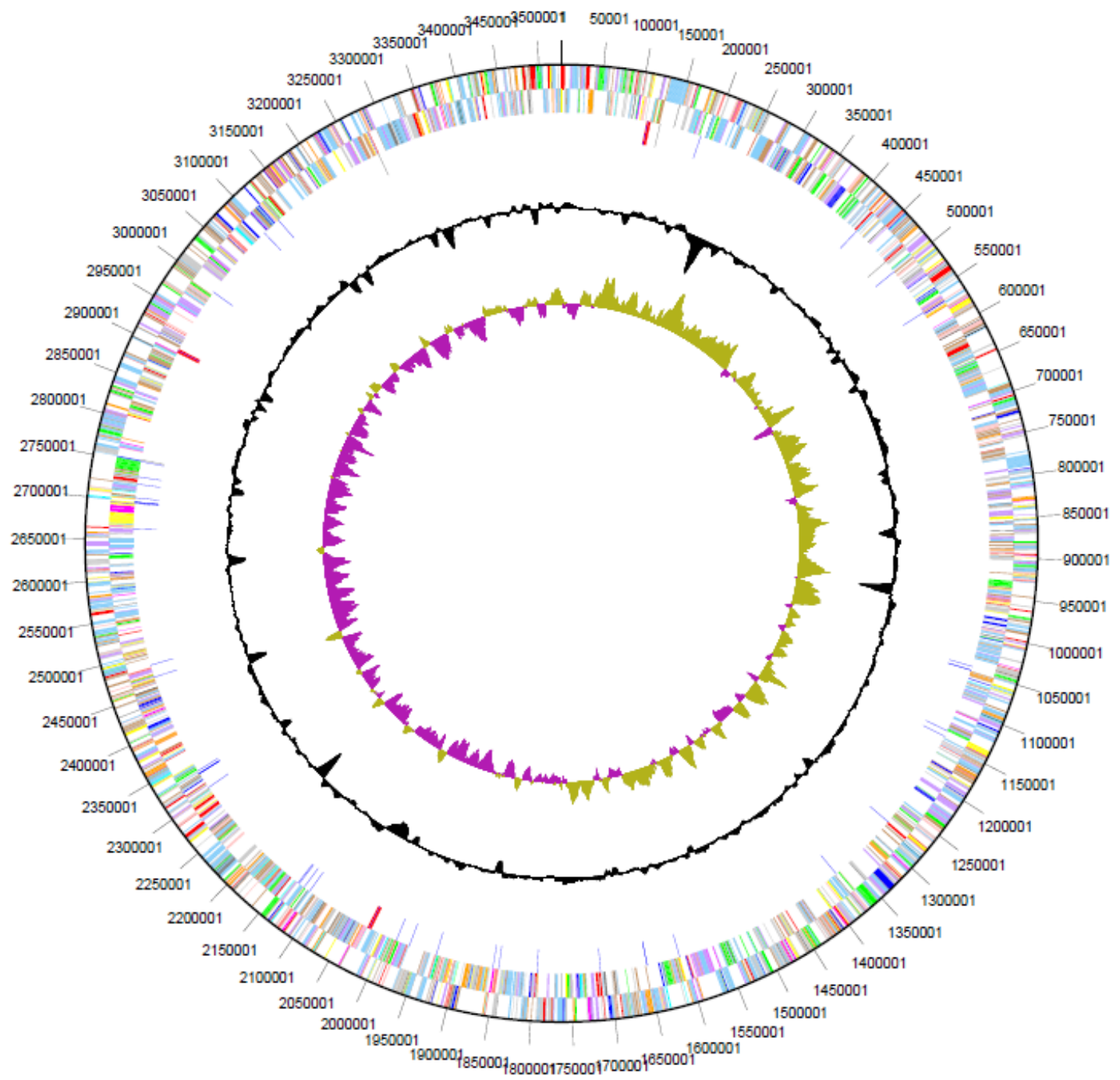

Figure 3. Graphical circular map of the chromosome. From outside to the center: Genes on forward strand (color by COG categories), Genes on reverse strand (color by COG categories), RNA genes (tRNAs green, rRNAs red, other RNAs black), GC content, GC skew.

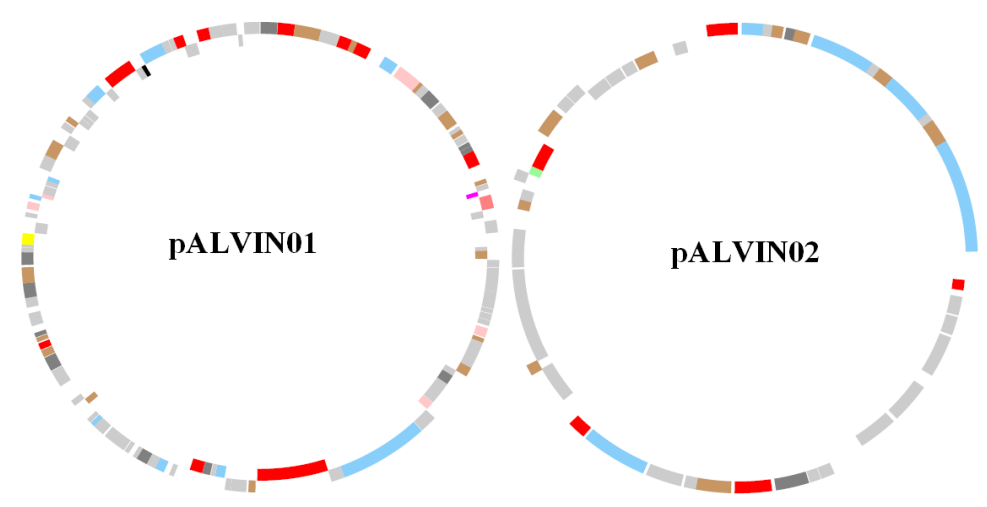

Figure 4. Graphical circular map of the $102.2 \mathrm{kbp}$ plasmid pALVIN01 (127 genes including 8 pseudogenes) and the $39.9 \mathrm{kbp}$ plasmid pALVIN02 (49 genes including 1 pseudogene). From outside to the center: Genes on forward strand (color by COG categories), Genes on reverse strand (color by COG categories), RNA genes (tRNAs green, rRNAs red, other RNAs black), GC content, GC skew. 


\section{Diffusible electron carriers}

During photosynthesis, diffusible electron carriers maintain light-driven cyclic electron flow by channeling electrons from the cytochrome $b_{1}$ complex back to the reaction center. In most cases this feature is mediated by mobile, soluble electron-carrying proteins located in the periplasm. In non-sulfur purple bacteria, the high potential cytochrome $c_{2}$ represents the main diffusible electron carrier. However, in A. vinosum cytochrome $\mathrm{c}_{2}$ function is replaced by other high potential c-type cytochromes and a high potential iron sulfur protein (HiPIP) [50]. HiPIP is encoded by Alvin_2274 with an N-terminal signal peptide for periplasmic translocation [51] and is able to act as direct reductant for the reaction center in $A$. vinosum [52,53] and other Chromatiaceae [54-56]. It occurs in high concentrations and is favored over high potential c-type cytochromes under photolithoautotrophic conditions [53]. HiPIP was also shown to operate as an acceptor of electrons released by thiosulfate dehydrogenase during oxidation of thiosulfate [57]. Besides HiPIP, the genome of $A$. vinosum reveals the genetic information for several high potential c-type cytochromes. Alvin_1694 encodes for cytochrome $\mathrm{c}_{8}\left(\mathrm{c}_{551}\right)$ that is involved in transferring electrons to the photosynthetic reaction center [58]. It appears in lower amounts than HiPIP but the ratio of HiPIP to cytochrome $\mathrm{c}_{8}$ is slightly higher under autotrophic conditions with $\mathrm{Na}_{2} \mathrm{~S}$ and $\mathrm{Na}_{2} \mathrm{~S}_{2} \mathrm{O}_{3}$ than in presence of organic compounds [53]. Similar to Rubrivivax gelatinosus [59] in A. vinosum appears at least one cytochrome $\mathrm{c}_{8}$ isoenzyme, namely $\mathrm{Al}$ vin_1093 encodes for a cytochrome that is part of flavocytochrome c. The protein expressed by Alvin_2879 reveals high similarities to the flavocytochome c diheme subunit [60] and its amino acid sequence is nearly identical to recently discovered cytochrome $c_{4}$ of Thiocapsa roseopersicina [61]. It is reported to appear both in a soluble and a membrane-bound form in A. vinosum [62]. Cytochrome c' is another high potential c-type cytochrome encoded by Alvin_2765 [63] with no clearly determined function up to date. It was postulated to take part in electron transfer [64] but also to bind NO [65] in order to provide resistance to nitric oxide [66]. Besides these already well described cytochromes the genome reveals three more potential diffusible c-type cytochromes, namely Alvin_0020, Alvin_0023 and Alvin_1846. Alvin_0020 and Alvin_0023 are annotated as soluble diheme c-type cytochromes and are localized in adjacent gene clusters of unknown function. Alvin_1846 is annotated as a further isoenzyme of cytochrome $\mathrm{c}_{8}$ and blast searches reveal most similarities to a cytochrome $\mathrm{c}_{553}$ from Magnetospirillum gryphiswaldense MSR-1.

\section{Autotrophic growth with carbon dioxide}

In a wide range of autotrophic organisms, the ability to grow autotrophically with carbon dioxide as the sole carbon source is due to the enzyme ribulose 1,5-biphosphate carboxylase/oxygenase (RuBis-CO). A. vinosum possesses two complete sets of genes encoding for large and small RuBis-CO subunits namely $\mathrm{RbcA} / \mathrm{RbcB}$ and $\mathrm{RbcS} / \mathrm{RbcL}$ represented by Alvin_1365/1366 and Alvin_2749/2750, respectively [67]. RuBis-CO of $\mathrm{RbcAB}$ is the major species present in $A$. vinosum under standard photolithoautotrophic growth conditions [68]. According to the gene arrangement, RuBis-CO genes $r b c A B$ belong to form IAq RuBis-CO genes that are typically associated with $c b b Q$ genes that encode for proteins affecting activity of RuBis-CO [69]. Upstream, a gene encoding for a member of the LysR family of transcriptional regulators might regulate expression of $r b c A B$ [70]. RuBis-CO genes rbcSL represent form IAc RuBis-CO genes that are always associated together with a cluster of $\alpha$-carboxysome genes [71]. Expression studies in Hydrogenovibrio marinus revealed a preferential expression of RuBis-CO form IAc at low $\mathrm{CO}_{2}$ concentrations, whereas expression of form IAq predominates at high $\mathrm{CO}_{2}$ concentrations. Thus RuBis-CO RbcSL in cooccurrence with carboxysomes might allow $A$. vinosum to grow at very low $\mathrm{CO}_{2}$ concentration. But so far carboxysomes have never been reported for $A$. vinosum. Interestingly, downstream of $r b c L$ a second gene for a small subunit of RuBis$\mathrm{CO}$ is found but its role during carbon dioxide fixation still has yet to be determined. Besides the RuBis-CO genes dedicated to carbon fixation, $A$. vinosum harbors a gene (Alvin_2545) encoding for a form IV RuBis-CO-like protein (RLP). These types of RuBis-CO enzymes do not catalyze ribulose 1,5-bisphosphate dependent $\mathrm{CO}_{2}$ fixation but might be involved in sulfur metabolism and stress response [72,73] as well as in methionine salvage pathway [71]. The role of the RLP in A. vinosum is still not resolved. 
Table 4. Number of genes associated with the general COG functional categories

\begin{tabular}{crrl}
\hline Code & Value & \%age & Description \\
\hline J & 160 & 5.70 & Translation, ribosomal structure and biogenesis \\
A & 1 & 0.04 & RNA processing and modification \\
K & 106 & 3.78 & Transcription \\
L & 145 & 5.17 & Replication, recombination and repair \\
B & 1 & 0.04 & Chromatin structure and dynamics \\
D & 51 & 1.82 & Cell cycle control, cell division, chromosome partitioning \\
Y & 0 & 0.00 & Nuclear structure \\
V & 49 & 1.75 & Defense mechanisms \\
T & 303 & 10.80 & Signal transduction mechanisms \\
M & 198 & 7.06 & Cell wall/membrane biogenesis \\
N & 1,135 & 4.81 & Cell motility \\
Z & 0 & 0.0 & Cytoskeleton \\
W & 0 & 0.0 & Extracellular structures \\
U & 84 & 2.99 & Intracellular trafficking and secretion \\
O & 126 & 4.49 & Posttranslational modification, protein turnover, chaperones \\
C & 224 & 7.98 & Energy production and conversion \\
G & 101 & 3.60 & Carbohydrate transport and metabolism \\
E & 148 & 5.27 & Amino acid transport and metabolism \\
F & 54 & 1.92 & Nucleotide transport and metabolism \\
H & 159 & 5.67 & Coenzyme transport and metabolism \\
I & 63 & 2.25 & Lipid transport and metabolism \\
P & 172 & 6.13 & Inorganic ion transport and metabolism \\
Q & 41 & 1.46 & Secondary metabolites biosynthesis, transport and catabolism \\
R & 261 & 9.30 & General function prediction only \\
S & 224 & 7.98 & Function unknown \\
- & 861 & 25.58 & Not in COGs \\
\hline & & & \\
\hline
\end{tabular}

\section{Dissimilatory sulfur metabolism}

The capability to oxidize reduced sulfur compounds is the central feature of $A$. vinosum during photolithoautotrophic growth. Light energy is used to transfer electrons from reduced sulfur compounds to the level of the more highly reducing electron carriers $\mathrm{NAD}(\mathrm{P})^{+}$and ferredoxin for reductive carbon dioxide fixation. The most abundant reduced sulfur component in the habitat of $A$. vinosum is sulfide but up to the time of publication of this report, it is still not clear which enzymes are responsible for sulfide oxidation in A. vinosum. One possibility is the oxidation via a soluble periplasmic flavocytochrome c. The protein is a heterodimer consisting of a $21 \mathrm{kDa}$ di-heme cytochrome c subunit (FccA) and a $46 \mathrm{kDa}$ flavin- binding subunit (FccB) [2]. Both subunits are represented in the genome of $A$. vinosum by $\mathrm{Al}-$ vin_1093 and Alvin_1092, respectively. Flavocytochrome c catalyzes the oxidation of sulfide to sulfur or polysulfides in vitro using soluble c-type cytochromes as electron acceptors [74] but the exact role of this protein in vivo is still not resolved. Mutants in which the genes $f c c A B$ are inactivated by a kanamycin cassette oxidize sulfide with rates similar to the wild type [74]. Some sulfide-utilizing green sulfur bacteria, e.g. Chlorobium luteolum (formerly Pelodictyon luteolum), and purple sulfur bacteria, e.g. Thiocapsa roseopersicina, Thiococcus pfennigii (formerly Thiocapsa pfennigii) and Allochromatium warmingii (formerly 
Chromatium warmingii), do not produce flavocytochrome c, which is an additional hint that flavocytochrome $\mathrm{c}$ is not essential for sulfide oxidation [2].

Other candidate proteins for oxidizing sulfide are sulfide:quinone oxidoreductases (SQRs). This type of enzyme catalyzes the oxidation of sulfide with an isoprenoid quinone as electron acceptor. SQR activity was shown to occur biochemically in membrane-bound form in A. vinosum [74]. Polysulfides were identified as main reaction products in vitro for Rhodobacter capsulatus [75] that might further react chemically [76] or enzymatically [77] to sulfur for storage in sulfur globules. Sequence data reveal two genes encoding for SQRs in $A$. vinosum (Alvin_1195 and Alvin_2145). Alvin_2145 represents a SQR of type IV [78], of which SqrD, an orthologous enzyme, is responsible for most of the SQR activity in the green sulfur bacterium Chlorobaculum tepidum $[79,80]$. A correlation between the occurrence of SqrD and the production of intracellular sulfur globules has been noted: $s q r D$ genes are present in members of the Chromatiaceae (e.g. Thiococcus pfennigii, Thioflavicoccus mobilis and Marichromatium purpuratum) while they are absent in those species of the family Ectothiorhodospiraceae that produce exclusively extracellular sulfur globules [78]. The enzyme encoded by Alvin_1195 belongs to type VI SQRs. The orthologous enzyme SqrF of $C$. tepidum is important for growth at high sulfide concentrations [78].

The sox gene cluster of the chemolithoautotrophic Alphaproteobacterium Paracoccus pantotrophus comprises 15 genes that encode proteins involved in the oxidation of thiosulfate, whereas the protein products of 7 genes soxXYZABCD are sufficient for oxidizing thiosulfate in vitro $[81,82]$. In $A$. vinosum, sox genes are separated into three gene clusters. Cluster one comprises Alvin_2108 to Alvin_2112. However, only Alvin_2011 and Alvin_2012 encode for Sox proteins, namely SoxY and SoxZ. The second gene cluster extends between Alvin_2165 and Alvin_2167 with Alvin_2167 encoding for SoxB. The third gene cluster includes Alvin_2168 to Alvin_2182, where SoxX, SoxA, SoxK and SoxL are encoded by Alvin_2168 to Alvin_2171. The additional genes of cluster three mainly encode for cytochrome c biogenesis proteins. The Sox protein complex is localized in the periplasm. In $A$. vinosum SoxCD activity of $P$. pantotrophus probably is replaced by sulfur transferase activity of SoxL transferring the sulfane atom for storage to sulfur globules, thus regenerating the cysteine residue of SoxY [83]. SoxK acts as binding protein keeping SoxX and SoxA together.

Under slightly acidic conditions thiosulfate is increasingly oxidized to tetrathionate via thiosulfate dehydrogenase encoded by Alvin_0091 [84]. This periplasmic enzyme is a c-type cytochrome and acts as monomer [84].

Rhodaneses (thiosulfate sulfurtransferases) are enzymes that catalyze the transfer of the sulfane sulfur atom of thiosulfate to cyanide producing thiocyanate ( $\left.\mathrm{SCN}^{-}\right)$and $\mathrm{SO}_{3}{ }^{2-}$ in vitro. In addition to SoxL, six other genes are annotated that might encode rhodaneses, namely Alvin_0258, Alvin_0866, Alvin_0868, Alvin_1587, Alvin_2599 and Alvin_3028. While Alvin_0258 encodes a signal peptide for periplasmic localization Alvin_3028 is proposed to encode a transmembrane protein. The remaining proteins lack both a signal peptide and transmembrane domains and are therefore expected to be cytoplasmic. Roles for these proteins in dissimilatory sulfur metabolism are currently unclear.

Uptake and oxidation of external, insoluble elemental sulfur by $A$. vinosum and other purple sulfur bacteria as well as by green sulfur bacteria is still unresolved and the A. vinosum genome does not reveal any new insights.

Oxidation of sulfide, thiosulfate and sulfur leads to the formation of sulfur globules in the periplasm for storage of still oxidizeable sulfur compounds. The envelope of these globules consists of three constitutively synthesized hydrophobic proteins, namely SgpA, SgpB and SgpC that are encoded by Alvin_1905, Alvin_0358 and Alvin_1325, respectively. SgpC plays an important role in globule expansion, whereas SgpA and SgpB can be replaced by each other to some extent $[85,86]$. Sulfur inside these globules is present as mono- and bis-organyl sulfanes [87]. For further oxidation of stored sulfur globules sulfur probably is reductively activated and transported into the cytoplasm via a perthiolic carrier molecule. For oxidation of stored sulfur the dissimilatory sulfite reductase (Dsr), proteins are of essential importance since several A. Vinosum $d s r$ mutants are unable to oxidize stored sulfur. Dsr proteins are encoded by a single dsrABEFHCMKLJOPNRS gene cluster extending from Alvin_1251 to Alvin_1265. Transferred sulfur could be released in the cytoplasm from the perthiolic organic carrier molecule as sulfide and 
subsequently transferred to dissimilatory sulfite reductase Dsr AB via a sulfur relay system involving the proteins DsrC and DsrEFH. DsrAB is homologous to sulfite reductase of sulfate-reducing organisms [88] and therefore might operate in the opposite direction in sulfur-reducing prokaryotes $[89,90]$. Electrons released from the oxidation might be fed into the photosynthetic electron transport via the transmembrane DsrMKJOP complex [91]. DsrN probably catalyzes the glutamine dependent amidation of siroheme, a cofactor of DsrAB. The function of DsrL, DsrR and DsrS is still not resolved but DsrL appears to play an essential role during oxidation of stored sulfur since $d s r L$ in-frame mutants are unable to oxidize stored sulfur [92-97]. While the $d s r$ genes are transcribed as one single element, $d s r C$ and $d s r S$ each have an additional independent promoter site [98].

Besides $d s r C$, there are four more genes annotated as TusE/DsrC/DsvC family sulfur relay proteins, namely Alvin_0028, Alvin_0345, Alvin_0732 and Alvin_1508. Whether the encoded proteins are involved in dissimilatory sulfur metabolism and/ or thiouridine biosynthesis as reported for TusE in Escherichia coli [99] and possibly in other cellular processes remains to be established.

Detection of all necessary enzymes for oxidation of sulfite to sulfate has still not been achieved. Indirect oxidation of sulfite to sulfate can take place via APS reductase and ATP sulfurylase. Both enzymes are encoded in A. vinosum by Alvin_1119 to Alvin_1121 and Alvin_1118, respectively. APS reductase is membrane-bound via AprM encoded by Alvin_1119. Both APS reductase and ATP sulfurylase seem to have only a minor influence on sulfite oxidation in $A$. vinosum since mutants with inactivated $a p r A B$ genes reveal sulfite oxidation rates similar to the wild type [100]. Other interesting genes encoding for proteins probably involved in dissimilatory sulfur metabolism are represented by Alvin_1317 to Alvin_1319. These genes encode for sulfur reductase subunits annotated as SreA, SreB and SreC with the ability also to reduce polysulfide in Archaea. Subunit SreA is predicted to occur in the periplasm. Blast searches reveal high similarities to corresponding genes in Acidithiobacillus ferrooxidans and other sulfur oxidizing Bacteria and Archaea [101] but the specific function in $A$. vinosum still has to be determined.

\section{Heterotrophic growth with organic substrates}

With respect to utilizable substrates as electron donators for photosynthesis, A. vinosum is very versatile. Besides autotrophic growth with reduced sulfur compounds, $A$. vinosum is able to assimilate a great number of organic substrates during photoorganoheterotrophic growth [21]. Fumarate, succinate, malate and pyruvate are oxidized by a complete tricarboxylic acid cycle. Similarly, acetate is utilized, converting it to acetyl-CoA via acetate-CoA-ligase (Alvin_0165) or the successive reactions of acetate kinase (Alvin_0610) and phosphate acetyltransferase (Alvin_0609). Propionate might be channeled into tricarboxylic acid cycle for oxidation at the stage of succinyl-CoA, but the enzyme responsible for converting 2methylcitrate to 3-hydroxybutane-1,2,3-tricarboxylate is still not detected. Formate and glycolate are utilized as electron donators via formate dehydrogenase (Alvin_2451-2454) and glycolate dehydrogenase (Alvin_0157-0158, 0174 and 1931), respectively. Malate synthase G (Alvin_2606) catalyzes the formation of malate from glyoxylate, which can then enter the tricarboxylic acid cycle. Heterotrophic growth with butyrate is reported as variable [21]. This observation is consistent with the fact that the genome sequence reveals no obvious genes encoding proteins for butyrate oxidation. Although $A$. vinosum possesses the complete enzymatic facility for glycolysis, this organism is not able to grow with glucose as an electron donor. This incapability is probably due to the lack of a phosphotransferase system for glucose uptake.

\section{Chemotrophy}

Besides phototrophic growth, A. vinosum is also able to grow chemotrophically with oxygen as an electron acceptor under low oxygen concentration [26]. The genome sequence of $A$. vinosum reveals the presence of two oxidases working preferentially under microaerobic conditions. Alvin_2499 and Alvin_2500 encode for a cytochrome $b d$ oxidase that is widely distributed among Archaea and Bacteria [102]. The function of the $b d$ oxidase is to scavenge toxic oxygen during nitrogen fixation as it was shown to be co-transcribed with a nitrogen fixation related gene that is located upstream of oxidase subunit I [26]. Furthermore, A. vinosum possesses a cytochrome $c b b_{3}$ oxidase (Alvin_0781 to Alvin_0784), a member of the heme-copper oxidase family. Cytochrome $c b b_{3}$ oxidase is characterized by its ability to maintain catalytic activity 
under low oxygen concentration and the capability to translocate protons. The genomic arrangement corresponds to the well characterized $c b b_{3}$ oxidase of Rhodobacter capsulatus [103].

\section{Hydrogenases}

Hydrogenases are oxidoreductases with the ability either to oxidize hydrogen as energy source or to produce hydrogen as an electron sink. According to their metal content, hydrogenases are divided into $\mathrm{NiFe}, \mathrm{FeFe}$ and iron sulfur free hydrogenase classes. The genome of $A$. vinosum reveals the presence of four individual $\mathrm{NiFe}$ hydrogenases. The typical protein structure of NiFe hydrogenases is heterodimeric and the correct folding, maturation and incorporation of ligands require accessory proteins. The membrane-bound hydrogenase of $A$. vinosum DSM 185 encoded by Alvin_2036 and Alvin_2039 in strain DSM $180^{\mathrm{T}}$ is well characterized [104]. The structural genes hydS and hydL are separated by an intergenic sequence encoding a membrane-bound b-type cytochrome and a soluble iron-sulfur protein, respectively, with similarities to DsrM and DsrK $[105,106]$. Genomic organization corresponds to hynSL (former hydSL) in the photosynthetic bacterium Thiocapsa roseopersicina BBS, also belonging to the family Chromatiaceae [107]. Hyn hydrogenase is membranebound facing the periplasmic side, constitutively expressed, and physiologically connected to cellular redox processes via the proteins encoded by the intergenic sequence $[108,109]$. Besides HydSL, A. vinosum encodes for a second membrane associated hydrogenase that is highly similar to T. roseopersicina HupSLC. In A. vinosum, hupC (Alvin_2307) encodes for a b-type cytochrome, hupL (Alvin_2308) and hupS (Alvin_2309) for large and small hydrogenase subunits, respectively. While the accessory hupDHI genes are required for hydrogenase biosynthesis in T. roseopersicina [110], in A. vinosum only hupD (Alvin_2306) is available. Hup hydrogenase of $T$. roseopersicina is also membrane-bound facing the periplasm, inducible and is involved in the oxidation of $\mathrm{H}_{2}$ occurring in the environment or resulting from nitrogenase activity. The b-type cytochrome represented by HupC participates in channeling electrons into the quinone pool $[108,109]$. High sequence similarities between $T$. roseopersicina and $A$. vinosum Hup hydrogenases might result in at least a similar localization and function. A soluble hydrogenase was recently characterized in A. vinosum DSM 185 [111] belonging to the HoxEFUYH type of [NiFe] hydrogenases. It consists of a hydrogenase HoxYH and a diaphorase HoxFU containing binding sites for flavin mononucleotide and $\mathrm{NAD}(\mathrm{H})$ in subunit HoxF. HoxE is the fifth subunit and is suggested to play a role in electron transfer as this was reported for the homologous hydrogenase complex in T. roseopersicina [112,113]. The HoxEFUYH type of hydrogenases is evolutionarily most closely related to complex I [111]. In A. vinosum DSM $180^{\mathrm{T}}$, Hox hydrogenase is encoded by the genes Alvin_1864 to Alvin_1868 followed by a gene (Alvin_1869) encoding for a hydrogenase maturation protein, namely HoxW. In T. roseopersicina, HoxEFUYH seems to be connected to sulfur metabolism and dark and photofermentative processes [109]. A fourth NiFe hydrogenase is encoded by Alvin_0807 to Alvin_0810. Blast searches reveal similarities to hydrogenase/sulfur reductase of Thermodesulfovibrio yellowstonii DSM 11347 and Chlorobium tepidum, but the exact function and localization still has to be determined. Besides hydrogenase gene clusters, there are several genes annotated for hydrogenase maturation distributed all over the genome such as Alvin_0054, Alvin_1451, Alvin_1958, Alvin_2766 and Alvin_2797 to Alvin_2799. A. vinosum is able to use hydrogen both for phototrophic and chemotrophic growth [21], but the role of the various hydrogenases in these processes still has to be determined.

\section{Nitrogen metabolism}

A. vinosum belongs to the diazotrophic bacteria encoding for iron-molybdenum dinitrogenase (nifDK) and dinitrogenase reductase (nifH). Genes involved in nitrogen fixation are spread all over the genome but always aggregated in gene clusters. The genome reveals that regulation takes place at least on two levels. Level one comprises the Ntr system consisting of the two component system NtrB/NtrC (Alvin_2998/Alvin_2997), nitrogen regulatory protein P-II (Alvin_0793) and the bifunctional uridylyltransferase/UMP-re-moving enzyme of P-II GlnD (Alvin_2042), that is located in the same gene cluster as the membrane-bound hydrogenase HydSL and might reflect a role of this hydrogenase in metabolizing $\mathrm{H}_{2}$, that is released during nitrogen fixation. The $\mathrm{NtrB} / \mathrm{NtrC}$ system regulates transcription of the NifA protein (Alvin_1291) required for transcription of all nif genes [114]. Usually post-translational control of NifA occurs on a second level by oxygen. Therefore NifA contains either conserved cysteine residues for direct interaction with oxygen as it has 
Weissgerber et al.

been reported for Bradyrhizobium japonicum [115] or NifA is inhibited by NifL after oxygen did interact with this protein [116]. Neither strategy is present in A. vinosum, which is in agreement with observations made for Halorhodospira halophila [117]. Perhaps the lack of oxygen sensing ability is compensated by direct post-translational modification of nitrogenase on level three. Reversible ADP-ribosylation of dinitrogenase reductase is mediated by dinitrogenase reductase ADP-ribosyl transferase (Alvin_1882) and dinitrogenase reductase activating glycohydrolase (Alvin_3044) in response to various exogenous stimuli $[118,119]$. Interestingly, just as in $H$. halophila the $A$. vinosum genome reveals three distinct $r n f$ gene clusters (Alvin_0562 to Alvin_0579, Alvin_1169 to Alvin_1179 and Alvin_2673 to Alvin_2681). The Rnf complex was shown to play a role in nitrogen fixation as overproduction of the $r n f$ operon increased nitrogenase activity in Rhodobacter capsulatus [120]. Furthermore, this complex connects the cellular ferredoxin to the pyridine nucleotide pool and was also shown to generate a sodium ion gradient across the cytoplasmic membrane in Acetobacterium woodii [121]. The role of Rnf complexes in $A$. vinosum is entirely unclear at this point in time. Gene arrangement in cluster one with a gene encoding for a sodium/hydrogen exchanger (Alvin_0576) for example does not exclude a function similar to that in $A$. woodii in generating a sodium gradient across the membrane. There are no obvious genes present in $A$. vinosum mediating dissimilatory or assimilatory nitrate reduction despite a single gene encoding for nitric oxide reductase subunit B (Alvin_0931)

\section{Acknowledgements}

This work was supported by grants Da 351/4-3, Da 351/5-1 and Da 351/6-1 from the Deutsche Forschungsgemeinschaft (DFG). We are grateful for the electron micrograph of an $A$. vinosum cell which was kindly provided by Hans G. Trüper, Bonn. The electron micrograph was made by HGT in the laboratory of Stanley W. Watson (Biological Laboratory, Woods Hole

\section{References}

1. Overmann J. Mahoney Lake: A case study of the ecological significance of phototrophic sulfur bacteria. Adv Microb Ecol 1997; 15:251-288.

2. Brune DC. Sulfur oxidation by phototrophic bacteria. Biochim Biophys Acta 1995; 975:189-221. PubMed

3. Soli G. Microbial degradation of cyclonite (RDX). Naval Weapons Center TP5525; 1973. p. 1-4. and the two component regulatory system NarX and NarL (Alvin_1057 and Alvin_1058) for sensing nitrite and nitrate.

\section{Assimilatory sulfur metabolism}

Assimilatory sulfate reduction occurs in a variety of phototrophic purple bacteria. In contrast to more specialized species within the Chromatiaceae and Ectothiorhodospiraceae, A. vinosum is able to grow photoorganoheterotrophically and therefore is able to assimilate sulfate as sulfur source. Assimilatory sulfate reduction starts with the uptake of sulfate from the environment by an ABC transporter encoded by Alvin_2443 to Alvin_2441 and annotated as cysTWA [122]. Downstream, on the opposite strand, gene Alvin_2444 encodes for a periplasmic sulfate binding protein (CysP) mediating sulfate to the transport system. In the cytoplasm, sulfate is activated by the formation of a phosphate-sulfate anhydride bond resulting in adenosine 5'-phosphosulfate (APS). This reaction is catalyzed by the assimilatory heterodimeric ATP-sulfurylase encoded by Alvin_2448 and Alvin_2449 and annotated as cysDN [123]. APS is either directly reduced to sulfide by assimilatory APS reductase ( $\mathrm{cys} H$ ) and sulfite reductase (cysI) (Alvin_2447 and Alvin_2446) for incorporation in cysteine for further utilization or shuttled into a second pathway. Here, APS is initially phosporylated to phosphoadenosine phosphosulfate (PAPS) via APS kinase (CysC) encoded by Alvin_1127 [123].

Oceanogrophic Institution, Woods Hole, MA, USA) with the participation of Charles C. Remsen III and John B. Waterbury. The work conducted by the U.S. Department of Energy Joint Genome Institute is supported by the Office of Science of the U.S. Department of Energy under Contract No. DE-AC02-05CH11231.

4. Siefert E, Irgens RL, Pfennig N. Phototropic purple and green bacteria in a sewage treatment plant. Appl Environ Microbiol 1978; 35:38-44. PubMed

5. Kobayashi M, Kobayashi M. Waste remediation and treatment using anoxygenic phototrophic bacteria. In: Blankenship RE, Madigan MT, Bauer $\mathrm{CE}$, editors. Anoxygenic photosynthetic bacteria. Dordrecht: Kluwer Academic Publishers; 1995. p 1269-1282. 
6. Sasikala C, Ramana CV. Biotechnological potentials of anoxygenic phototrophic bacteria. 1. Production of single-cell protein, vitamins, ubiquinones, hormones, and enzymes and use in waste treatment. Adv Appl Microbiol 1995; 41:173-226. PubMed doi:10.1016/S0065-2164(08)70310-1

7. Sasikala C, Ramana CV. Biotechnological potentials of anoxygenic phototrophic bacteria. 2. Biopolyesters, biopesticide, biofuel, and biofertilizer. Adv Appl Microbiol 1995; 41:227-278. PubMed doi:10.1016/S0065-2164(08)70311-3

8. Liebergesell $M$, Steinbüchel A. New knowledge about the pha-locus and $\mathrm{P}(3 \mathrm{HB})$ granuleassociated proteins in Chromatium vinosum. Biotechnol Lett 1996; 18:719-724. doi:10.1007/BF00130772

9. Sasikala K, Ramana CV, Rao PR, Kovács KL. Anoxygenic photosynthetic bacteria: physiology and advances in hydrogen production technology. Adv Appl Microbiol 1993; 38:211-295. doi:10.1016/S0065-2164(08)70217-X

10. Euzéby JP. List of prokaryotic names with standing in nomenclature. http://www.bacterio.cict.fr.

11. Field D, Garrity G, Gray T, Morrison N, Selengut J, Sterk P, Tatusova T, Thomson N, Allen MJ, Angiuoli $\mathrm{SV}$, et al. The minimum information about a genome sequence (MIGS) specification. Nat Biotechnol 2008; 26:541-547. PubMed doi:10.1038/nbt1360

12. Woese CR, Kandler O, Wheelis ML. Towards a natural system of organisms: proposal for the domains Archaea, Bacteria, and Eucarya. Proc Natl Acad Sci USA 1990; 87:4576-4579. PubMed doi:10.1073/pnas.87.12.4576

13. Garrity GM, Bell JA, Lilburn T. Phylum XIV. Proteobacteria phyl. nov. In: Garrity GM, Brenner DJ, Krieg NR, Staley JT (eds), Bergey's Manual of Systematic Bacteriology, Second Edition, Volume 2, Part B, Springer, New York, 2005, p. 1.

14. List Editor. Validation of publication of new names and new combinations previously effectively published outside the IJSEM. List no. 106. Int J Syst Evol Microbiol 2005; 55:2235-2238. doi:10.1099/ijs.0.64108-0

15. Garrity GM, Bell JA, Lilburn T. Class III. Gammaproteobacteria class. nov. In: Garrity GM, Brenner DJ, Krieg NR, Staley JT (eds), Bergey's Manual of Systematic Bacteriology, Second Edition, Volume 2, Part B, Springer, New York, 2005, p. 1.

16. Imhoff J. Order I. ord. nov. In: Garrity GM, Brenner DJ, Krieg NR, Staley JT (eds), Bergey's Manual of Systematic Bacteriology, Second Edition, Volume 2, Part B, Springer, New York, 2005, p. 1-3.

17. Skerman VBD, McGowan V, Sneath PHA. Approved Lists of Bacterial Names. Int / Syst Bacteriol 1980; 30:225-420. doi:10.1099/00207713$\underline{30-1-225}$

18. Bavendamm W. Die farblosen und roten Schwefelbakterien des Süss- und Salzwassers. In: Kolkwitz R (ed), Pflanzenforschung, Gustav Fischer, Jena,

19. Imhoff JF. Reassignment of the Genus Ectothiorhodospira Pelsh 1936 to a new family, Ectothiorhodospiraceae fam. nov., and emended description of the Chromatiaceae Bavendamm 1924. Int J Syst Bacteriol 1984; 34:338-339. doi:10.1099/00207713-34-3-338

20. Imhoff JF, Süling J, Petri R. Phylogenetic relationships among the Chromatiaceae, their taxonomic reclassification and description of the new genera Allochromatium, Halochromatium, Isochromatium, Marichromatium, Thiococcus, Thiohalocapsa and Thermochromatium. Int I Syst Bacteriol 1998; 48:1129-1143. PubMed doi:10.1099/00207713-48-4-1129

21. Imhoff JF. Genus II. Allochromatium. In: Brenner DJ, Krieg NR, Staley JT, Garrity GM, editors. Bergey's Manual of Systematic Bacteriology. 2 ed. Volume 2 B. New York: Springer; 2005. p 12-14.

22. Bundesanstalt für Arbeitsschutz und Arbeitsmedizin. http://www.baua.de/de/Startseite.html.

23. German Collection of Microorganisms and Cell Cultures. http://www.dsmz.de.

24. Ashburner M, Ball CA, Blake JA, Botstein D, Butler $\mathrm{H}$, Cherry JM, Davis AP, Dolinski K, Dwight SS, Eppig JT, et al. Gene ontology: tool for the unification of biology. The Gene Ontology Consortium. Nat Genet 2000; 25:25-29. PubMed doi:10.1038/75556

25. Cole JR, Chai B, Farris RJ, Wang Q, Kulam-SyedMohideen AS, McGarrell DM, Bandela AM, Cardenas E, Garrity GM, Tiedje JM. The ribosomal database project (RDP-II): introducing myRDP space and quality controlled public data. Nucleic Acids Res 2007; 35:D169-D172. PubMed doi:10.1093/nar/gkl889

26. Dincturk HB, Demir V, Aykanat T. Bd oxidase homologue of photosynthetic purple sulfur bacterium Allochromatium vinosum is co-transcribed with a nitrogen fixation related gene. Antonie van Leeuwenhoek 2011; 99:211-220. PubMed doi:10.1007/s10482-010-9478-5 
Weissgerber et al.

27. Liolios K, Chen IM, Mavromatis K, Tavernarakis N, Hugenholtz P, Markowitz VM, Kyrpides NC. The Genomes On Line Database (GOLD) in 2009: status of genomic and metagenomic projects and their associated metadata. Nucleic Acids Res 2010; 38:D346-D354. PubMed doi:10.1093/nar/gkp848

28. Weaver PF, Wall JD, Gest H. Characterization of Rhodopseudomonas capsulata. Arch Microbiol 1975; 105:207-216. PubMed doi:10.1007/BF00447139

29. Bazaral M, Helinski DR. Circular DNA forms of colicinogenic factors E1, E2 and E3 from Escherichia coli. J Mol Biol 1968; 36:185-194. PubMed doi:10.1016/0022-2836(68)90374-4

30. Bennett S. Solexa Ltd. Pharmacogenomics 2004; 5:433-438. PubMed doi:10.1517/14622416.5.4.433

31. Margulies $M$, Egholm $M$, Altman WE, Attiya $S$, Bader JS, Bemben LA, Berka J, Braverman MS, Chen YJ, Chen Z, et al. Genome sequencing in microfabricated high-density picolitre reactors. Nature 2005; 437:376-380. PubMed

32. DOE Joint Genome Institute. http://www.jgi.doe.gov

33. Zerbino DR, Birney E. Velvet: algorithms for de novo short read assembly using de Bruijn graphs. Genome Res 2008; 18:821-829. PubMed doi:10.1101/gr.074492.107

34. The Phred/Phrap/Consed software package. http://www.phrap.com

35. Ewing B, Hillier L, Wendl MC, Green P. Basecalling of automated sequencer traces using phred. I. Accuracy assessment. Genome Res 1998; 8:175-185. PubMed

36. Green P, Ewing B. Base-calling of automated sequencer traces using phred. II. Error probabilities. Genome Res 1998; 8:186-194. PubMed

37. Gordon D, Abajian C, Green P. Consed: A graphical tool for sequence finishing. Genome Res 1998; 8:195-202. $\underline{\text { PubMed }}$

38. Han CS, Chain P. Finishing repeat regions automatically with Dupfinisher. In: Arabnia HR, Valafar $\mathrm{H}$, editors. Proceeding of the 2006 international conference on bioinformatics \& computational biology. Las Vegas, NV: CSREA Press; 2006. p 141-146.

39. Hyatt D, Chen GL, Locascio PF, Land ML, Larimer FW, Hauser LJ. Prodigal: prokaryotic gene recognition and translation initiation site identifi- cation. BMC Bioinformatics 2010; 11:119.

PubMed doi:10.1186/1471-2105-11-119

40. Pati A, Ivanova NN, Mikhailova N, Ovchinnikova G, Hooper SD, Lykidis A, Kyrpides NC. GenePRIMP: a gene prediction improvement pipeline for prokaryotic genomes. Nat Methods 2010; 7:455-457. PubMed doi:10.1038/nmeth.1457

41. Lowe TM, Eddy SR. tRNAscan-SE: A program for improved detection of transfer RNA genes in genomic sequence. Nucleic Acids Res 1997; 25:955-964. PubMed doi:10.1093/nar/25.5.955

42. Lagesen K, Hallin P, Rodland EA, Staerfeldt HH, Rognes T, Ussery DW. RNAmmer: consistent and rapid annotation of ribosomal RNA genes. Nucleic Acids Res 2007; 35:3100-3108. PubMed doi:10.1093/nar/gkm160

43. Griffiths-Jones S, Bateman A, Marshall M, Khanna A, Eddy SR. Rfam: an RNA family database. Nucleic Acids Res 2003; 31:439-441. PubMed doi:10.1093/nar/gkg006

44. Krogh A, Larsson B, von Heijne G, Sonnhammer ELL. Predicting transmembrane protein topology with a hidden Markov model: Application to complete genomes. J Mol Biol 2001; 305:567580. PubMed doi:10.1006/jmbi.2000.4315

45. Bendtsen JD, Brunak S, Nielsen H, von Heijne G. Improved prediction of signal peptides: SignalP 3.0. J Mol Biol 2004; 340:783-795. PubMed doi:10.1016/j.jmb.2004.05.028

46. Pattaragulwanit K, Dahl C. Development of a genetic system for a purple sulfur bacterium: Conjugative plasmid transfer in Chromatium vinosum. Arch Microbiol 1995; 164:217-222. doi:10.1007/BF02529974

47. Gaju N, Pavon V, Marin I, Esteve I, Guerrero R. Chromosome map of the phototrophic anoxygenic bacterium Chromatium vinosum. FEMS Microbiol Lett 1995; 126:241-247. doi:10.1111/j.15746968.1995.tb07425.x

48. Nagashima S, Shimada K, Matsuura K, Nagashima KV. Transcription of three sets of genes coding for the core light-harvesting proteins in the purple sulfur bacterium, Allochromatium vinosum. Photosynth Res 2002; 74:269-280. PubMed doi:10.1023/A:1021280104053

49. Mechler B, Oelze J. Differentiation of photosynthetic apparatus of Chromatium vinosum, strain D. III. Analyses of spectral alterations. Arch Microbiol 1978; 118:109-114. doi:10.1007/BF00406082 
50. Bartsch RG. The distribution of soluble metalloredox proteins in purple phototrophic bacteria. Biochim Biophys Acta 1991; 1058:28-30. PubMed doi:10.1016/S0005-2728(05)80262-2

51. Brüser T, Trüper HG, Dahl C. Cloning and sequencing of the gene encoding the high potential iron-sulfur protein (HiPIP) from the purple sulfur bacterium Chromatium vinosum. Biochim Biophys Acta 1997; 1352:18-22. PubMed

52. Kennel SJ, Bartsch RG, Kamen MD. Observations on light-induced oxidation reactions in the electron transport system of Chromatium. Biophys J 1972; 12:882-896. PubMed doi:10.1016/S0006$\underline{3495(72) 86131-9}$

53. Verméglio A, Li J, Schoepp-Cothenet B, Pratt N, Knaff DB. The role of high-potential iron protein and cytochrome c(8) as alternative electron donors to the reaction center of Chromatium vinosum. Biochemistry 2002; 41:8868-8875. PubMed doi:10.1021/bi012037h

54. Schoepp B, Parot P, Menin L, Gaillard J, Richaud $\mathrm{P}$, Verméglio A. In vivo participation of a high potential iron-sulfur protein as electron donor to the photochemical reaction center of Rubrivivax gelatinosus. Biochemistry 1995; 34:11736-11742. PubMed doi:10.1021/bi00037a010

55. Hochkoeppler A, Ciurli S, Venturoli G, Zannoni D. The high potential iron-sulfur protein (HiPIP) from Rhodoferax fermentans is competent in photosynthetic electron transfer. FEBS Lett 1995; 357:70-74. PubMed doi:10.1016/0014$\underline{\text { 5793(94)01334-W }}$

56. Hochkoeppler A, Zannoni D, Ciurli S, Meyer TE, Cusanovich MA, Tollin G. Kinetics of photoinduced electron transfer from high-potential iron-sulfur protein to the photosynthetic reaction center of the purple phototroph Rhodoferax fermentans. Proc Natl Acad Sci USA 1996; 93:69987002. PubMed doi:10.1073/pnas.93.14.6998

57. Fukumori Y, Yamanaka T. Flavocytochrome c of Chromatium vinosum. Some enzymatic properties and subunit structure. J Biochem 1979; 85:14051414. PubMed

58. Van Grondelle V, Duysens LN, van der Wel JA, van der Wal HN. Function and properties of a soluble c-type cytochrome c-551 in secondary photosynthetic electron transport in whole cells of Chromatium vinosum as studied with flash spectroscopy. Biochim Biophys Acta 1977; 461:188201. PubMed doi:10.1016/0005-2728(77)90169$\underline{4}$
59. Menin L, Yoshida M, Jaquinod M, Nagashima KV, Matsuura K, Parot P, Vermeglio A. Dark aerobic growth conditions induce the synthesis of a high midpoint potential cytochrome c8 in the photosynthetic bacterium Rubrivivax gelatinosus. Biochemistry 1999; 38:15238-15244. PubMed doi:10.1021/bi991146h

60. Van Beeumen JJ, Demol H, Samyn B, Bartsch RG, Meyer TE, Dolata MM, Cusanovich MA. Covalent structure of the diheme cytochrome subunit and amino-terminal sequence of the flavoprotein subunit of flavocytochrome c from Chromatium vinosum. J Biol Chem 1991; 266:12921-12931. PubMed

61. Branca RM, Bodo G, Varkonyi Z, Debreczeny M, Osz J, Bagyinka C. Oxygen and temperaturedependent structural and redox changes in a novel cytochrome c(4) from the purple sulfur photosynthetic bacterium Thiocapsa roseopersicina. Arch Biochem Biophys 2007; 467:174-184. PubMed doi:10.1016/j.abb.2007.07.031

62. Cusanovich MA, Bartsch RG. A high potential cytochrome c from Chromatium chromatophores. Biochim Biophys Acta 1969; 189:245-255. $\underline{\text { PubMed doi:10.1016/0005-2728(69)90051-6 }}$

63. Evers TH, Merkx M. Successful recombinant production of Allochromatium vinosum cytochrome $C^{\prime}$ requires coexpression of $\mathrm{cmm}$ genes in hemerich Escherichia coli JCB712. Biochem Biophys Res Commun 2005; 327:668-674. PubMed doi:10.1016/j.bbrc.2004.12.062

64. Meyer TE, Cheddar G, Bartsch RG, Getzoff ED, Cusanovich MA, Tollin G. Kinetics of electron transfer between cytochromes $C^{\prime}$ and the semiquinones of free flavin and clostridial flavodoxin. Biochemistry 1986; 25:1383-1390. PubMed doi:10.1021/bi00354a029

65. Mayburd AL, Kassner RJ. Mechanism and biological role of nitric oxide binding to cytochrome $\mathrm{C}^{\prime}$. Biochemistry 2002; 41:11582-11591. PubMed doi:10.1021/bi020058l

66. Cross R, Aish J, Paston SJ, Poole RK, Moir JW. Cytochrome c' from Rhodobacter capsulatus confers increased resistance to nitric oxide. / Bacteriol 2000; 182:1442-1447. PubMed doi:10.1128/JB.182.5.1442-1447.2000

67. Viale AM, Kobayashi H, Akazawa T. Expressed genes for plant-type ribulose 1,5-bisphosphate carboxylase/oxygenase in the photosynthetic bacterium, which possesses two complete sets of the genes. J Bacteriol 1989; 171:2391-2400. PubMed 
68. Viale AM, Kobayashi H, Akazawa T. Distinct properties of products of plant-type ribulose-1,5bisphosphate carboxylase/oxygenase directed by two sets of genes from the photosynthetic bacterium Chromatium vinosum. J Biol Chem 1990;

265:18386-18392. PubMed

69. Hayashi NR, Arai H, Kodama T, Igarashi Y. The $c b b Q$ genes, located downstream of the form I and form II RubisCO genes, affect the activity of both RubisCOs. Biochem Biophys Res Commun 1999; 265:177-183. PubMed doi:10.1006/bbrc.1999.1103

70. Viale AM, Kobayashi H, Akazawa T, Henikoff S. $r b c R$ [correction of $r c b R$ ], a gene coding for a member of the LysR family of transcriptional regulators, is located upstream of the expressed set of ribulose 1,5-bisphosphate carboxylase/oxygenase genes in the photosynthetic bacterium Chromatium vinosum. J Bacteriol 1991; 173:5224-5229. PubMed

71. Badger MR, Bek EJ. Multiple Rubisco forms in Proteobacteria: their functional significance in relation to $\mathrm{CO}_{2}$ acquisition by the CBB cycle. J Exp Bot 2008; 59:1525-1541. PubMed doi:10.1093/jxb/erm297

72. Hanson TE, Tabita FR. A ribulose-1,5bisphosphate carboxylase/oxygenase (RubisCO)like protein from Chlorobium tepidum that is involved with sulfur metabolism and the response to oxidative stress. Proc Natl Acad Sci USA 2001; 98:4397-4402. PubMed doi:10.1073/pnas.081610398

73. Hanson TE, Tabita FR. Insights into the stress response and sulfur metabolism revealed by proteome analysis of a Chlorobium tepidum mutant lacking the Rubisco-like protein. Photosynth Res 2003; 78:231-248. PubMed doi:10.1023/B:PRES.0000006829.41444.3d

74. Reinartz M, Tschäpe J, Brüser T, Trüper HG, Dahl C. Sulfide oxidation in the phototrophic sulfur bacterium Chromatium vinosum. Arch Microbiol 1998; 170:59-68. PubMed doi:10.1007/s002030050615

75. Griesbeck C, Schütz M, Schodl T, Bathe S, Nausch L, Mederer N, Vielreicher M, Hauska G. Mechanism of sulfide-quinone reductase investigated using site-directed mutagenesis and sulfur analysis. Biochemistry 2002; 41:11552-11565. PubMed doi:10.1021/bi026032b

76. Steudel R. Mechanism for the formation of elemental sulfur from aqueous sulfide in chemical and microbiological desulfurization processes.
Ind Eng Chem Res 1996; 35:1417-1423.

doi:10.1021/ie950558t

77. Frigaard NU, Dahl C. Sulfur metabolism in phototrophic sulfur bacteria. Adv Microb Physiol 2009; 54:103-200. PubMed doi:10.1016/S00652911(08)00002-7

78. Gregersen LH, Bryant DA, Frigaard NU. Mechanisms and evolution of oxidative sulfur metabolism in green sulfur bacteria. Front Microbiol 2011; 2:116. PubMed

79. Chan LK, Morgan-Kiss RM, Hanson TE. Functional analysis of three sulfide:quinone oxidoreductase homologs in Chlorobaculum tepidum. J Bacteriol 2009; 191:1026-1034. PubMed doi:10.1128//B.01154-08

80. Holkenbrink C, Ocon Barbas S, Mellerup A, Otaki $\mathrm{H}$, Frigaard NU. Sulfur globule oxidation in green sulfur bacteria is dependent on the dissimilatory sulfite reductase system. Microbiology 2011.

81. Rother D, Friedrich CG, Henrich HJ, Quentmeier A, Bardischewsky F. Novel genes of the sox gene cluster, mutagenesis of the flavoprotein SoxF, and evidence for a general sulfur-oxidizing system in Paracoccus pantotrophus GB17. I Bacteriol 2001; 183:4499-4508. PubMed doi:10.1128/|B.183.15.4499-4508.2001

82. Friedrich CG, Bardischewsky F, Rother D, Quentmeier A, Fischer J. Prokaryotic sulfur oxidation. Curr Opin Microbiol 2005; 8:253-259. PubMed doi:10.1016/j.mib.2005.04.005

83. Welte C, Dahl C, Hafner S, Krätzer C, Quentmeier A, Friedrich CG. Interaction between Sox proteins of two physiologically distinct bacteria and a new protein involved in thiosulfate oxidation. FEBS Lett 2009; 583:1281-1286. PubMed doi:10.1016/j.febslet.2009.03.020

84. Hensen D, Dahl C, Sperling D, Trüper HG, Brune DC. Thiosulphate oxidation in the phototrophic sulphur bacterium Allochromatium vinosum. Mol Microbiol 2006; 62:794-810. PubMed doi:10.1111/j.1365-2958.2006.05408.x

85. Pattaragulwanit K, Brune DC, Trüper HG, Dahl C. Molecular genetic evidence for extracytoplasmic localization of sulfur globules in Chromatium vinosum. Arch Microbiol 1998; 169:434-444. PubMed doi:10.1007/s002030050594

86. Prange A, Engelhardt H, Trüper HG, Dahl C. The role of the sulfur globule proteins of Allochromatium vinosum: mutagenesis of the sulfur globule protein genes and expression studies by real-time 
RT-PCR. Arch Microbiol 2004; 182:165-174. PubMed doi:10.1007/s00203-004-0683-3

87. Prange A, Dahl C, Trüper HG, Chauvistré R, Modrow $\mathrm{H}$, Hormes J. X-ray absorption spectroscopy of bacterial sulfur globules: a detailed reply. Microbiology 2002; 148:2268-2270.

88. Loy A, Duller S, Baranyi C, Mussmann M, Ott J, Sharon I, Beja O, Le Paslier D, Dahl C, Wagner M. Reverse dissimilatory sulfite reductase as phylogenetic marker for a subgroup of sulfuroxidizing prokaryotes. Environ Microbiol 2009; 11:289-299. PubMed doi:10.1111/j.1462$\underline{2920.2008 .01760 . x}$

89. Schedel M, Trüper HG. Purification of Thiobacillus denitrificans siroheme sulfite reductase and investigation of some molecular and catalytic properties. Biochim Biophys Acta 1979; 568:454466. PubMed

90. Schedel M, Vanselow M, Trüper HG. Siroheme sulfite reductase isolated from Chromatium vinosum. Purification and investigation of some of its molecular and catalytic properties. Arch Microbiol 1979; 121:29-36. doi:10.1007/BF00409202

91. Grein F, Pereira IA, Dahl C. Biochemical characterization of individual components of the Allochromatium vinosum DsrMKJOP transmembrane complex aids understanding of complex function in vivo. J Bacteriol 2010; 192:6369-6377. PubMed doi:10.1128/JB.00849-10

92. Pott AS, Dahl C. Sirohaem sulfite reductase and other proteins encoded by genes at the $d s r$ locus of Chromatium vinosum are involved in the oxidation of intracellular sulfur. Microbiology 1998; 144:1881-1894. PubMed doi:10.1099/00221287144-7-1881

93. Dahl C, Engels S, Pott-Sperling AS, Schulte A, Sander J, Lübbe Y, Deuster O, Brune DC. Novel genes of the $d s r$ gene cluster and evidence for close interaction of Dsr proteins during sulfur oxidation in the phototrophic sulfur bacterium Allochromatium vinosum. J Bacteriol 2005;

187:1392-1404. PubMed

doi:10.1128/JB.187.4.1392-1404.2005

94. Sander J, Engels-Schwarzlose S, Dahl C. Importance of the DsrMKJOP complex for sulfur oxidation in Allochromatium vinosum and phylogenetic analysis of related complexes in other prokaryotes. Arch Microbiol 2006; 186:357-366. PubMed doi:10.1007/s00203-006-0156-y

95. Lübbe YJ, Youn HS, Timkovich R, Dahl C. Siro(haem)amide in Allochromatium vinosum and relevance of DsrL and DsrN, a homolog of coby- rinic acid a,c-diamide synthase, for sulphur oxidation. FEMS Microbiol Lett 2006; 261:194-202. PubMed doi:10.1111/j.1574-6968.2006.00343.x

96. Cort JR, Selan U, Schulte A, Grimm F, Kennedy MA, Dahl C. Allochromatium vinosum DsrC: solution-state NMR structure, redox properties, and interaction with DsrEFH, a protein essential for purple sulfur bacterial sulfur oxidation. J Mol Biol 2008; 382:692-707. PubMed doi:10.1016/j.jmb.2008.07.022

97. Dahl C, Schulte A, Stockdreher Y, Hong C, Grimm F, Sander J, Kim R, Kim SH, Shin DH. Structural and molecular genetic insight into a widespread sulfur oxidation pathway. J Mol Biol 2008; 384:1287-1300. PubMed doi:10.1016/j.jmb.2008.10.016

98. Grimm F, Dobler N, Dahl C. Regulation of $d s r$ genes encoding proteins responsible for the oxidation of stored sulfur in Allochromatium vinosum. Microbiology 2010; 156:764-773. PubMed doi:10.1099/mic.0.034645-0

99. Ikeuchi Y, Shigi N, Kato J, Nishimura A, Suzuki T. Mechanistic insights into sulfur relay by multiple sulfur mediators involved in thiouridine biosynthesis at tRNA wobble positions. Mol Cell 2006; 21:97-108. PubMed doi:10.1016/j.molcel.2005.11.001

100. Dahl C. Insertional gene inactivation in a phototrophic sulphur bacterium: APS-reductasedeficient mutants of Chromatium vinosum. Microbiology 1996; 142:3363-3372. PubMed doi:10.1099/13500872-142-12-3363

101. Laska S, Lottspeich F, Kletzin A. Membranebound hydrogenase and sulfur reductase of the hyperthermophilic and acidophilic archaeon Acidianus ambivalens. Microbiology 2003;

149:2357-2371. PubMed

doi:10.1099/mic.0.26455-0

102. Castresana J. Evolution and phylogenetic analysis of respiration. In: Zannoni D, editor. Respiration in Archaea and Bacteria. Diversity of prokaryotic electron transport carriers. Dordrecht: Kluwer Academic Publishers; 2004. p 1-4.

103. Pitcher RS, Watmough NJ. The bacterial cytochrome cbb3 oxidases. Biochim Biophys Acta 2004; 1655:388-399. PubMed doi:10.1016/j.bbabio.2003.09.017

104. Kellers P, Lubitz W, Ogata H. Purification, crystallization and preliminary $\mathrm{X}$-ray analysis of the membrane-bound [NiFe] hydrogenase from Allochromatium vinosum. Acta Crystallogr Sect F 
Struct Biol Cryst Commun 2008; 64:719-722. PubMed doi:10.1107/S1744309108019945

105. Dahl C, Rakhely G, Pott-Sperling AS, Fodor B, Takacs M, Toth A, Kraeling M, Gyorfi K, Kovács A, Tusz J, et al. Genes involved in hydrogen and sulfur metabolism in phototrophic sulfur bacteria. FEMS Microbiol Lett 1999; 180:317-324. PubMed doi:10.1111/j.1574-6968.1999.tb08812.x

106. Liang Y, Wu X, Gan L, Xu H, Hu Z, Long M. Increased biological hydrogen production by deletion of hydrogen-uptake system in photosynthetic bacteria. Microbiol Res 2009; 164:674-679. PubMed doi:10.1016/j.micres.2009.03.001

107. Rakhely G, Kovács KL, Colbeau A, Garin J, Vignais PM. Unusual organization of the genes coding for HydSL, the stable [NiFe]hydrogenase in the photosynthetic bacterium Thiocapsa roseopersicina BBS. J Bacteriol 1998; 180:1460-1465. PubMed

108. Palágyi-Mészáros LS, Maroti J, Latinovics D, Balogh T, Klement E, Medzihradszky KF, Rakhely G, Kovács KL. Electron-transfer subunits of the NiFe hydrogenases in Thiocapsa roseopersicina BBS. FEBS / 2009; 276:164-174. PubMed doi:10.1111/j.1742-4658.2008.06770.x

109. Maróti J, Rakhely G, Farkas A, Nagy IK, Maroti G, Kondorosi E, Kovács KL. A second soluble HoxType NiFe enzyme completes the hydrogenase set in Thiocapsa roseopersicina BBS. Appl Environ Microbiol 2010; 76:5113-5123. PubMed doi:10.1128/AEM.00351-10

110. Colbeau A, Kovács KL, Chabert J, Vignais PM. Cloning and sequence of the structural (hupSLC) and accessory (hupDHI) genes for hydrogenase biosynthesis in Thiocapsa roseopersicina. Gene 1994; 140:25-31. PubMed doi:10.1016/03781119(94)90726-9

111. Long M, Liu J, Chen Z, Bleijlevens B, Roseboom W, Albracht SP. Characterization of a HoxEFUYH type of [NiFe] hydrogenase from Allochromatium vinosum and some EPR and IR properties of the hydrogenase module. I Biol Inorg Chem 2007; 12:62-78. PubMed doi:10.1007/s00775-006$\underline{0162-1}$

112. Rákhely G, ács AT, Maroti G, Fodor BD, Csanadi G, Latinovics D, Kovacs KL. Cyanobacterial-type, heteropentameric, NAD+-reducing NiFe hydrogenase in the purple sulfur photosynthetic bacterium Thiocapsa roseopersicina. Appl Environ Microbiol 2004; 70:722-728. PubMed doi:10.1128/AEM.70.2.722-728.2004
113. Rákhely G, Laurinavichene TV, Tsygankov AA, Kovács KL. The role of Hox hydrogenase in the $\mathrm{H}_{2}$ metabolism of Thiocapsa roseopersicina. Biochim Biophys Acta 2007; 1767:671-676. PubMed doi:10.1016/j.bbabio.2007.02.004

114. Dixon R. The oxygen-responsive NIFL-NIFA complex: a novel two-component regulatory system controlling nitrogenase synthesis in $\gamma$ proteobacteria. Arch Microbiol 1998; 169:371380. PubMed doi:10.1007/s002030050585

115. Fischer HM. Genetic regulation of nitrogen fixation in Rhizobia. Microbiol Rev 1994; 58:352386. $\underline{\text { PubMed }}$

116. Martinez-Argudo I, Little R, Dixon R. A crucial arginine residue is required for a conformational switch in NifL to regulate nitrogen fixation in Azotobacter vinelandii. Proc Natl Acad Sci USA 2004; 101:16316-16321. PubMed doi:10.1073/pnas.0405312101

117. Tsuihiji H, Yamazaki Y, Kamikubo H, Imamoto Y, Kataoka M. Cloning and characterization of nif structural and regulatory genes in the purple sulfur bacterium, Halorhodospira halophila. J Biosci Bioeng 2006; 101:263-270. PubMed doi:10.1263/jbb.101.263

118. Nordlund S. Regulation of nitrogenase activity in phototrophic bacteria reversible covalent modification. In: Triplett EW, editor. Prokaryotic nitrogen fixation: A model system for analysis of a biological process. Wymondham: Horizon Scientific Press; 2000. p 149-164.

119. Gotto JW, Yoch DC. Regulation of nitrogenase activity by covalent modification in Chromatium vinosum. Arch Microbiol 1985; 141:40-43. PubMed doi:10.1007/BF00446737

120. Jeong HS, Jouanneau Y. Enhanced nitrogenase activity in strains of Rhodobacter capsulatus that overexpress the rnf genes. J Bacteriol 2000;

182:1208-1214. PubMed doi:10.1128/JB.182.5.1208-1214.2000

121. Biegel E, Müller V, Schmidt S, Gonzalez JM. Biochemistry, evolution and physiological function of the Rnf complex, a novel ion-motive electron transport complex in prokaryotes. Cell Mol Life Sci 2011; 68:613-634. PubMed doi:10.1007/s00018-010-0555-8

122. Hryniewicz MM, Kredich NM. The cysP promoter of Salmonella typhimurium: characterization of two binding sites for CysB protein, studies of in vivo transcription initiation, and demonstration of the anti-inducer effects of thiosulfate. I Bacteriol 1991; 173:5876-5886. PubMed 
123. Neumann S, Wynen A, Trüper HG, Dahl C. Characterization of the cys gene locus from Allochromatium vinosum indicates an unusual sulfate assimilation pathway. Mol Biol Rep 2000; 27:27-

33. PubMed doi:10.1023/A:1007058421714 